\title{
Letting go of control to the learners: the role of the Internet in promoting a more autonomous view of learning in an academic translation course
}

\section{Ayye Yumuk}

To cite this article: Ayye Yumuk (2002) Letting go of control to the learners: the role of the Internet in promoting a more autonomous view of learning in an academic translation course, Educational Research, 44:2, 141-156, DOI: 10.1080/00131880210135278

To link to this article: http://dx.doi.org/10.1080/00131880210135278

Published online: 02 Dec 2010.

Submit your article to this journal $\sqsubset$

Џلll Article views: 263

Q View related articles ๘

Citing articles: 9 View citing articles $\square$ 


\section{Letting go of control to the learners: the role of the Internet in promoting a more autonomous view of learning in an academic translation course}

Ayşe Yumuk, School of Applied Languages, Bilkent University, Ankara, Turkey

\section{Summary}

This study investigates how an Internet information search based programme in an academic course can encourage learners who have a traditional view of learning to take more responsibility for their own learning. The study took place with 90 third-year English-speaking translation students whose native language is Turkish in a course specializing in written translation of financial and economic terms at a university in Turkey. The study aimed to design and evaluate a programme to promote a change in students' attitudes from a traditional, recitationbased view of learning to a more autonomous view of learning. The programme was implemented to encourage students to use the Internet in order to select, analyse, evaluate and apply relevant information to enhance the accuracy of their translations. The search and application of the Internet-based information aimed to encourage students to think and reflect critically on their learning, so that they could question their teacher-dependent learning habits. The evaluation of the programme was carried out with reference to pre- and post-course questionnaires, post-course interviews and information recorded weekly in a diary by the teacher as researcher. The results indicate that the programme had a significant impact on students, in that it promoted a change in the view of learning towards more autonomy. After applying Internet-based information searches to their written translation tasks, the majority of the students accepted that the translation process required more personal responsibility from the learner, and furthermore, they viewed learning more meaningfully.

Keywords: Internet-based information search, critical thinking, critical reflection, learner autonomy, translation

Address for correspondence: Dr Ayșe Yumuk, School of Applied Languages, Bilkent University, Main Campus, Ankara, Turkey. Tel: 009031229019 87. Fax: 0090312266 43 83. E-mail: yumuk@bilkent.edu.tr 


\section{Introduction}

In some formal educational contexts, recitation is a common teaching mode (Holec, 1979; Tharp and Gallimore, 1988). Recitation-based teaching mainly encourages learners to develop skills to master school knowledge, which involves the memorization of information learned at school, rather than action knowledge, which encompasses critical reflection on new information and its application into a wider context. The actual success of learning is achieved when school knowledge is integrated with action knowledge, a task requiring more responsibility and control from learners (Barnes, 1976). Otherwise, 'learning becomes abstract and removed from reality and as a result less likely to engage intrinsic motivational processes, since students are unable to make a meaningful connection between what is learned and what is experienced in life outside' (Condry, 1978, cited in Ushioda, 1996, p. 42).

\section{Letting go of control to the learner: promoting a change in the view of learning}

Learner autonomy, that is learners' 'ability to take charge of [their] own learning', requires the development of a capacity (Holec, 1979, p. 3), resulting in successful and effective learning (Vygotsky, 1962, 1978; Holec, 1979; Kolb, 1984; Fox, 1991; Kohonen, 1992; Salomon, 1993; Piaget, cited in Smith, 1996). In the development of the capacity for autonomy, being aware or conscious of learning is essential in establishing the highest level of mental activity in learners (Vygotsky, 1978, cited in Marti, 1996). Critical reflection, which entails critical thinking about one's own learning, is therefore integral to the learning process which aims to develop the capacity for autonomy, in order to encourage learners to exercise responsibility for their own learning (Little, 1991, 1999, 2000; Dam, 1995; Dam and Little, 1998).

Critical reflection initiates learner control and self-assessment, which can lead not only to the development of analysis, synthesis and evaluation skills (Boud, 1981, 1995; Kemmis, 1989; Little, 1999), but also to an increased understanding of 'what', 'why', 'how' and 'with what degree of success' students are learning (Holec, 1979; Tharp and Gallimore, 1988; Holec, Little and Richterich, 1996; Lier, 1996; Dam, 1995, 2000). Such an increased understanding of the learning process enhances learners' desire and curiosity for more learning which, as a result, shapes their innate capacity for autonomy and develops their ownership of the learning process (Vygotsky, 1978; Piaget, cited in Wellman, 1990; Piaget, cited in Butterworth et al., 1991; Deci, 1996).

\section{The role of the Internet in letting go of control to the learner}

As a new way of processing information, the Internet can encourage learners not only to view themselves as being in charge of their own learning, but also to perceive teachers as facilitators in their learning process. Unlike resources such as textbooks, journals and other materials used in traditional teaching and learning, the Internet can stimulate learners to find the most updated information in a shorter amount of time. The Internet, with its hyper-linking capabilities to sources from all over the world, gives learners instant access to an enormous 
amount of information which, as a result, can enhance their desire and curiosity to learn more (Kenny, 1993; Forsyth, 1996; Peterson, 1997; Grey, 1999; Lyman, 1999; French, 1999; Collis and Meeuwsen, 1999; Johnson, 1999).

Internet access can also encourage learners to select the most recent, useful and applicable materials and decide how best to make use of them for their learning, unlike learning in which professionals such as teachers or textbook authors have the opportunity to assess the quality of the learning resources. As a result of their active involvement in and ownership of Internet-based information searches for their own learning, learners can understand that learning is not a process in which teachers have complete control, but one in which they themselves can actively make decisions (Little, 1996; Bett et al., 1999; Lyman, 1999; French, 1999; Collis and Meeuwsen, 1999).

\section{Context for the study}

In Turkey recitation is a common mode of teaching in both the primary and secondary educational systems. The majority of learners undergo the process of learning through traditional educational methods in which the teacher is the 'authority' rather than the 'facilitator'. The teacher-student relationship is mainly limited to one-way channels of communication in which teachers transfer information to learners. The assessment of learner performance is generally productoriented rather than process-oriented, mainly a summative evaluation in the form of exams that are based upon learners' memorization of information they have learned in the course (Akarsu, 1990; Bilhan, 1991; Yildirim, 1997; Titiz, 1998; Engin and Yildirim, 1999; Balci and Yildirim, 1999).

In addition, a limited number of studies looking into the quality of secondary school instruction in Turkey and how it prepares learners to think critically at the university level indicate that the majority of students entering university lack necessary critical thinking and reflection skills to cope with the requirements of academic life because of their teacher-dependent learning habits (Karasar, 1974; Bilhan, 1991; Guruz et al., 1994; Yildirim, 1997). Moreover, students have underdeveloped knowledge of how to plan, monitor and evaluate research at all educational levels (Karasar, 1984; Buyukozturk, 1996; Karagul, 1996).

Because learners are required to take responsibility and find their own methods of gathering, analysing, synthesizing and evaluating information at the university level (Stewart and Stoller, 1990; Tynjala, 1997), learners need metacognitive skills such as power of reflection, decision-making and independent action (Little, 1999). This study aims to indicate how the use of the Internet in an academic translation course encourages a change in the view of learners who have teacher-dependent learning habits to perceive learning as a process requiring more responsibility from the learner.

\section{Method of the study: design and evaluation of the programme}

This study formed an action research investigation, the process in which the consequences of educational decisions are systematically evaluated and practices adjusted to maximize effectiveness. In this study, the researcher was also the teacher of the course, who designed, implemented, evaluated and reported the programme studied (McLean, 1995; McKernan, 1996). 
The programme implemented in the study aimed to encourage learners in an academic translation course specializing in financial and economic terms, in Turkey, to use the Internet in order to select, analyse, evaluate and apply information to enhance accuracy in translation. It further targeted the stimulation of critical thinking and critical reflection in order to encourage learners to question their traditional views of learning.

Programme design was conducted in two stages: field-testing and programme implementation. Field-testing of the programme was carried out during the fall semester of 1998. At this stage, data collection instruments were piloted, and necessary changes were made. At the second stage, the actual programme was implemented and evaluated with the adjusted instruments during the spring semesters of 1999 and 2000.

\section{Instruments}

The data were collected using pre- and post-course questionnaires, post-course interviews and a weekly diary kept by the researcher. The pre- and post-course questionnaires used one open-ended question and $11 \mathrm{yes} / \mathrm{no} / \mathrm{explain}$ questions to measure whether there was a change in learners' traditional, teacher-dependent view of learning towards a more autonomous view in which learning requires more responsibility from the learner (see Appendix A).

The post-course interviews consisted of eight questions (see Appendix B). They aimed at finding out changes in the learners' perception of (1) translation; (2) difficulties in the translation process; and (3) their learning process. Interviews were conducted with a total of 15 students.

In the weekly diary, the researcher recorded changes in the attitudes of the learners at each of the four phases of the course: (1) negotiation of the curriculum goals; (2) training learners for Internet searches; (3) actual use of Internet searches for translation; and (4) reflection and feedback.

\section{Sample}

Participants in the field-testing of the programme consisted of 13 third-year translation students. Ninety third-year translation students were involved in the actual implementation of the programme, with 25 students in the spring of 1999 and 65 in the spring of 2000. Actual data from the questionnaires were collected from only 85 out of 90 students, because of low attendance from five of the students.

\section{Phases of the programme}

\section{Phase 1: Negotiation of the curriculum goals}

The purpose of the first phase was to enable learners to become aware of the aims of the course curriculum (Lier, 1996). At the beginning of the course, a classroom session was conducted with the learners to focus explicitly on what, why and how they were going to learn; how they were going to assess their progress; and how they could relate their academic learning to their real-life requirements (Dam, 1995, 2000; Dam and Little, 1998). In groups, they were asked to brainstorm topics, translation needs and necessary skills they felt were relevant to their area of study. Further, they were asked what methods of collecting information would support their translation needs (Newmark, 1988). Data from learners were recorded and discussed in groups. 


\section{TABLE 1 Applying Internet-based searches to translation tasks}

Eight steps

1 Analyse the source text for a general understanding of the topic

2 Identify applicable keywords for Internet searches

3 Apply keyword searches through the Internet

4 Analyse the Internet search information to understand better the topic and the specific terminology in the source translation text

5 Apply relevant Internet information and vocabulary while translating

6 Collaborate by discussing translations with other students for feedback and improvement

7 Submit at least three relevant Internet sources as evidence of Internet usage in translations

8 Prepare a terminology-specific glossary

\section{Phase 2: Training learners for Internet searches}

The purpose of this phase was to train learners on how to use the Internet in order to search, select, analyse, evaluate and apply information to enhance accuracy for the translation tasks in the course.

During this phase, students developed some basic Internet usage skills, such as how to type in URL addresses, how to use Internet search engines, writing keywords in search engines, clicking hyperlinks and understanding the differences among URL address extensions such as '.gov', '.com' and '.org'.

In addition, students were encouraged to do effective Internet searches to enhance accuracy in translation by applying four criteria: (1) doing Internet searches by specifying a keyword from the source translation text for deeper subject knowledge and terminology; (2) locating relevant Internet-based information for translation by scanning the Internet for relevant glossaries and subject information; (3) analysing Internet-based information for appropriate terminology use and subject knowledge requirements in translation tasks; and (4) doing further Internet searches on the problematic terminology and subject knowledge in the source translation text.

\section{Phase 3: Actual use of Internet searches for translation}

The aim of this phase was to encourage learners to view translation as a process as they followed the eight steps listed in Table 1, in order to apply Internet-based searches to translation tasks. The purpose of giving students eight steps to follow was to show them that translation can be a process requiring more responsibility from the learner rather than simply looking up words in a dictionary.

\section{Phase 4: Reflection and feedback}

Phase 4 aimed to encourage students to reflect on their learning process in order to become more conscious about what, why, how and with what degree of success they were learning during each translation task. During this phase in classroom sessions, students also discussed the accuracy of their translations for feedback and improvement.

During this phase, students reflected on both the process and actual use of Internet searches. Students expressed how they conducted their Internet searches, what information they located and what difficulties they encountered in this process. For their actual use of the Internet, they reported how they applied Internet-based 
TABLE 2 Assessment of learner progress

Category of assessment

\section{Formative}

Learner self-assessment:

Teacher assessment:

\section{Summative}

Teacher assessment:
Category of description

- Reflection upon learning process and performance

- Review of learners' Internet sources

- Review of learners' reflections on Internet searches and translation process

- Two mid-terms and a final exam, each involving Internet searches on the exam topic one-week prior

information to translation tasks, difficulties they had and what further sources, such as dictionaries or experts, they consulted in the process of translation.

\section{Assessment procedure}

Course assessment of learner progress was both formative and summative, and involved both the learner and the teacher (see Table 2). Learners formatively assessed their progress by reflecting upon their learning process and performance, using the four criteria discussed in phase 2 . The teacher's formative assessment involved review of: (1) each learner's three Internet sources submitted as evidence of his or her Internet usage for deeper subject knowledge and terminology search for translations; and (2) students' reflections on the process of applying Internet searches in translation (the eight steps they followed and difficulties they encountered).

Summative evaluation in the course involved two mid-terms and a final exam. Learners were given a topic one week before the exam, knowing that the text they would translate during the exam would be on this topic. They were to conduct Internet searches on this topic during the week prior to the exam and find at least three Internet sources. In addition to these three sources, they were allowed to bring any kind of dictionaries to the exam.

\section{Analysis of data}

Students' attitudes about learning were analysed by looking at the changes in their responses to identical questions in the pre- and post-course questionnaires. Responses to question 1 (an open-ended question) were coded into one of two categories. Yes/no responses to questions 2 through 12 were tested based on chisquare statistics. The post-course interview results were coded in relation to four categories of description (see above). The diary results were analysed in relation to changes in the attitudes of the learners recorded by the teacher in each of the four phases of the programme (see above).

\section{Results}

Pre-and post-course questionnaire results

The two categories of student description for question 1 in the pre- and postcourse questionnaires are shown in Table 3. When responding to the pre-course 
TABLE 3 Student responses to pre- and post-course questionnaires: Question 1

\begin{tabular}{lcc}
\hline Category of description & $\begin{array}{c}\text { Pre-course } \\
\text { responses (\%) }\end{array}$ & $\begin{array}{c}\text { Post-course } \\
\text { responses (\%) }\end{array}$ \\
\hline Word-by-word translation & 96.47 & 11.76 \\
Translation as a process & 3.52 & 88.23 \\
\hline
\end{tabular}

questionnaire, the majority of students described translation as a mechanical activity involving word-by-word translation using a dictionary. At the post-course questionnaire, however, the majority of students described translation as a process involving a series of activities such as text analysis; information searches from the Internet for deeper subject knowledge and understanding of terminology; drafting and redrafting; and glossary preparation. Their responses indicated that translating the source text by using only a dictionary would be insufficient for accurate translation. They also indicated that searches are necessary to learn more about the subject knowledge, as well as the use of specific terminology, in both the target language and the mother tongue.

Student responses to the other 11 questions in the pre- and post-course questionnaires are shown in Table 4. All responses to the post-course questionnaire were significantly different from those at the pre-course questionnaire, based on chi-square statistics. That is, the null hypothesis $\left(\mathrm{H}_{0}\right)$ that there is no difference between pre- and post-course responses was rejected because all responses were shown to be significantly different (attributable to chance less than 0.5 per cent of the time or $\alpha<0.005$, $\mathrm{df}=1$ ). While students' pre-course responses showed more teacher-dependent views of learning, their post-course responses changed significantly, indicating that they viewed translation and further learning as requiring more personal responsibility from the learner.

For example, questions 4 and 5 looked at students' previous learning methods. Approximately 7 per cent of the students reported being encouraged to question their learning method before taking the course, while approximately 88 per cent reported having done so at the end of the course. Moreover, none of the students reported being encouraged to question what method of learning was more applicable in real-life translations in the pre-course questionnaire, while nearly 92 per cent reported being encouraged to question such learning methods in the postcourse questionnaire.

Questions 11 and 12 asked students to assess their learning progress. In the pre-course questionnaire approximately 8 per cent of the students said they had not been encouraged to assess their progress in terms of subject knowledge, while in the post-course questionnaire approximately 94 per cent of the students said they had been motivated to assess their progress. Furthermore, none of the students reported being encouraged to self-assess their learning progress at a particular stage or overall in the pre-course questionnaire, while nearly 86 per cent reported doing so in the post-course questionnaire.

The least amount of change shown was in question 3, which asked students if they had been encouraged to do information searches for deeper terminology analysis in their translations. However, this change was still significant, with nearly 5 per cent answering 'yes' in the pre-course questionnaire, and nearly 58 per cent answering 'yes' in the post-course questionnaire (still a difference of over 50 per cent). 
TABLE 4 Student responses to pre- and post-course questionnaires: Questions 2-12

\begin{tabular}{|c|c|c|c|c|c|}
\hline \multirow[t]{2}{*}{ Questions } & \multirow{2}{*}{\multicolumn{2}{|c|}{$\begin{array}{c}\text { Pre-course } \\
\text { responses (\%) } \\
N=85\end{array}$}} & \multicolumn{2}{|c|}{$\begin{array}{c}\text { Post-course } \\
\text { responses (\%) } \\
N=85\end{array}$} & Chi-square \\
\hline & & & Yes & No & $\chi^{2^{*}}$ \\
\hline
\end{tabular}

Have you been encouraged to:

2 do information searches for deeper

$\begin{array}{lllll}7.05 & 92.94 & 85.88 & 14.11 & 106.15\end{array}$
subject knowledge for the source text to be translated?

3 do information searches for a deeper terminology (specific vocabulary) analysis for the source text to be translated?

4 question your learning method (how you learn)?

5 question what method of learning is more realistic/meaningful/applicable in real-life translations?

6 assess which method of learning is more meaningful to your own progress?

7 question the extent to which you base your analysis/translation of the source on data and evidence obtained through information searches?

8 assess the reliability of the evidence you obtain to enhance accuracy in your translation of the source text?

9 question how you can transfer the subject knowledge you learned in this course to your other academic courses and real-life situations when necessary?

10 question learning through information searches as meaningful and relevant to your needs in your other academic courses and real-life situations?

11 assess your progress of the subject knowledge you learned in this course?

12 assess your learning progress at a particular stage and overall?

$\begin{array}{lllll}4.70 & 95.29 & 57.64 & 42.35 & 55.51\end{array}$

$\begin{array}{lllll}7.05 & 92.94 & 88.23 & 11.76 & 112.27 \\ 0 & 100 & 91.76 & 8.23 & 144.13\end{array}$

$\begin{array}{lllll}9.41 & 90.58 & 78.82 & 21.17 & 83.05\end{array}$

$\begin{array}{lllll}12.94 & 87.05 & 100 & 0 & 131.04\end{array}$

$\begin{array}{lllll}2.35 & 97.64 & 90.58 & 9.41 & 133.01\end{array}$

$\begin{array}{lllll}4.70 & 95.29 & 94.11 & 5.88 & 135.92\end{array}$

$\begin{array}{lllll}3.52 & 96.47 & 76.47 & 18.82 & 94.21\end{array}$

Note:

${ }^{*}$ All the responses were found to be highly significant at $\alpha<0.005$ and $\mathrm{df}=1$ (because for all the responses $\chi^{2}>7.88$ ).

\section{Post-course interview results}

In the post-course interview, learnerswere asked about their perceptions of learning. Categories of learners' responses are shown in Table 5. The majority of students (60 per cent) reported that they perceived translation as a task requiring deeper analysis rather than only the use of a dictionary. When asked about 
TABLE 5 Student responses to post-course interview questions

Category of description

Post-course interview responses $\%$

$(N=15)$

\section{Learners' perception of translation as: ${ }^{\star}$}

- Requiring deeper information searches and analysis

- Involving responsibilities, including:

1 Internet-based information searches

2 Analysis and transfer of Internet-based information

3 Self-assessment of what, why and how Internet-based information searches were done

4 Class discussion, drafting and redrafting

5 Terminology-specific glossary preparation

- Not requiring deeper information searches and analysis

Total

Difficulties encountered by learners in the translation process: ${ }^{\dagger}$

- Selecting, analysing and transferring Internet-based information

- Conducting effective Internet-based information searches

- Choosing appropriate vocabulary

- Analysing sentence structures in the source text

\section{Learners' perception of their learning process as involving: ${ }^{\dagger}$}

- More learner responsibility

- More self-confidence in translation because of Internet-based information searches

- More interaction and discussions with peers

- Higher interest to learn more

- More self-assessment of learning

- More collaboration with peers for feedback and improvement

- More reflection on learning

- More learner control in learning

Note:

${ }^{\star}$ Only one response possible.

tMore than one response possible.

difficulties encountered in the translation process, all the students indicated that Internet searches were difficult in terms of selecting, analysing and transferring the information obtained. All the students indicated that the learning process required more responsibility on the part of the learner, while approximately half of the students stated that they had more peer interaction and discussion.

\section{Researcher's weekly diary results}

The results from the researcher's diary recorded at each phase of the programme indicated that in phase 1 the majority of learners expressed discontent about having too many responsibilities in the course, and questioned the relevance of applying Internet-based information searches to translation tasks. In phase 2 the majority expressed difficulties in selecting effective Internet-based keyword searches and choosing reliable Internet sources. In phase 3 the majority expressed difficulties in applying the eight steps of Internet-based searches to translation tasks, more apparently at the beginning and less apparently towards the end of 
the course. However, they also expressed the benefit of following the eight steps in preparation for translation tasks, and further showed higher participation in classroom discussions. In phase 4 the majority emphasized the difficulties of applying Internet-based information searches to translation tasks, and reflected on their experiences and assessed their progress since the beginning of the course.

As learners progressed in the course, they became more critical of their individual learning and more focused on their specific areas of weakness. For instance, learners expressed that before taking this course they were only doing word-by-word translations with the help of a dictionary rather than conducting deeper terminology searches with the help of the Internet.

\section{Discussion}

Assuming that change in learners' traditional view of learning from more to less teacher-dependent is an initial step towards taking more control over one's own learning (Lier, 1996; Little, 2000; Dam, 2000), the results of the study show the programme to be successful. At the beginning of the course, students were very unwilling to take responsibility for their own learning. They were not clear about the vital role of their commitment as learners to the learning process - that is, they placed most of the responsibility for their learning with the teacher (Yildirim, 1997; Titiz, 1998).

In the pre-course questionnaire the majority of students perceived translation as requiring only a dictionary, a text and the teacher as the main source of information. They were questioning the relevance of Internet-based subject knowledge and terminology searches in preparation for the highly mechanical task of translation, as shown in one of the students' remarks:

'I do not think I need any background or terminology searches before I translate a text. That is unnecessary and a waste of time for me. What I read in the text is usually enough for me to understand the text. I use a dictionary and then translate the text sentence by sentence. I ask the teacher when I do not find it in the dictionary.'

Later in the course, however, as students became actively involved in the learning process by searching for, analysing and transferring information from the Internet to translation tasks, the majority perceived translation as a process involving information searches with a series of activities rather than being simply a mechanical task. Moreover, despite the difficulties encountered in the process of conducting Internet-based information searches, students found such searches to be more relevant to the translation task than they had assumed at the beginning of the course. They started to gain a better understanding of Internet-based subject knowledge and subject-specific terminology searches, in order to enhance accuracy and meaning for their translations (Newmark, 1988). Furthermore, as indicated by one of the students in the post-course questionnaire, students also tended to collaborate with one another to receive feedback on their translations, an indication that learners themselves have the control in their own learning rather than the teacher:

'First, I read the text and do an Internet search on the subject . . . I generally use a dictionary at a later stage after I do the Internet search . . . and I 
think I understand the specific use of terminology in context not only in [English], but also in [Turkish]. When I feel the need, I do further Internet searches while translating, or sometimes I ask someone who knows more about the subject if I still have questions in my mind. I also check my translation by discussing it with my classmates. I think my translation becomes more accurate, and I trust my translation much better that way.'

The use of Internet searches in translation tasks encouraged students to think about and question their own learning as well (Forsyth, 1996; Collis and Meeuwsen, 1999; Grey, 1999; French, 1999), an indication that the Internetbased information search context of the course can promote a change in the view of passive and teacher-dependent learners to become more autonomous. As stated by one of the students in the post-course questionnaire, being selective in locating the Internet-based information to enhance accuracy for their translations encouraged students to question their passive, teacher-dependent learning habits and become more conscious about what, why and how they were learning (Little, 1996; Dam, 1995, 2000):

'I will make sure that I understand the text before I translate it. I will search for what I do not know. I will no longer memorize when I learn. First, I want to understand and learn what I am doing . . . I learned that I have to question what I am doing.'

Moreover, the students were encouraged to assess their own performance through reflections on how much and how well they had learned during the process of Internet-based information search translations (Little, 1996; Dam, 1995, 2000). Thus they gradually become more self-confident as they critically reflect on their weaknesses in the process of selecting, analysing and transferring information obtained through Internet searches (Boud, 1981, 1995; Little, 1999):

'I have difficulty especially when I translate from Turkish into English. I feel the need to do more searches, so that I can learn the specific use of a Turkish word in English . . . or sometimes when I translate from English into Turkish, I do not know how I can express a certain word in our mother tongue.'

Despite the difficulties encountered, the use of the Internet stimulated students' desire to learn more and apply what they learn in a wider context, an indication that learners become ready to take more responsibility when their learning engages their intrinsic motivation and they derive personal meanings from their own learning. Moreover, such an involvement in and ownership of the learning process encourages learners to be more empowered to take more control for their learning (Forsyth, 1996; Little, 1996; Collis and Meeuwsen, 1999; Grey, 1999; French, 1999; Bett et al., 1999; Johnson, 1999), as stated in the post-course interview by one student:

'From time to time, I wanted to do Internet searches not only for a translation task, but also for other courses or any other subjects that I find interesting to learn more about ... While taking this course, I thought that I needed an Internet connection at home to do Internet searches in a more relaxed situation from time constraints . . Now, I have my own Internet connection at home.' 


\section{Conclusion}

One of the main problems facing students entering university in Turkey is the prevailing view that the teacher is the dominant authority who controls learning, which contradicts the active role learners should take in academic contexts in order to process the flow of new information. When we consider the teacherdependent learning characteristics of most Turkish university students, it is possible to conclude that they need to view themselves undertaking more responsibility when selecting, analysing, evaluating and applying information for their purpose.

The study indicated that the Internet search-based academic translation course's impact on learners was positive, in that they were encouraged to perceive translation as a process requiring more responsibility from the learner rather than merely a text, a dictionary or the teacher as the source of information. Among the most important learner responsibilities in the process of translation were the use of the Internet to conduct information searches for translation tasks; the selection, analysis, evaluation and application of Internet-based information for deeper subject knowledge and understanding of terminology in translation tasks; reflection on the process of translation to identify areas of weakness; and collaboration with peers for feedback and improvement. The study also suggested that, as students reflected critically on the Internet-search information that was selected, analysed, evaluated and applied in the translation process, they developed an ownership of the learning process, in that they became more selfconfident in questioning their teacher-dependent learning habits.

As a relatively new way of processing information, the use of the Internet in academic translation courses can encourage learners to seek deeper subject knowledge and understanding of terminology for translations, and further, to view themselves as having more control to enhance their accuracy in translations. Moreover, Internet-based information searches promoted in this study can be applied in other academic fields in Turkey, so that learners can, again, view themselves as having more control over their own learning.

Especially at universities in Turkey, however, there might be some obstacles to surmount, if Internet-based teaching is to become widely available in order to promote learner autonomy and greater learner control over the learning process. One obstacle could be limited Internet access in many public universities in Turkey because of the scarcity of computers and other resources. Moreover, promoting a change in the teacher-dependent learning habits of Turkish students will require considerable time and effort. In order to encourage learners to take more responsibility, current teaching strategies and curricula that promote teacher-dependent learning habits rather than learner control at all levels of education in Turkey should be revised.

Furthermore, assuming that teacher willingness to participate in learner autonomy is integral in promoting a change in views of learners, certain time and effort is also required to promote changes in the attitudes of teachers at all educational levels in Turkey. Because teachers are also educated in the same Turkish educational system, where the teacher is the main authority in the classroom, it might be difficult for them to change their teaching strategies in a short period of time. Teacher education and in-service training programmes in Turkey could encourage the development of teacher characteristics as to being open-minded, flexible, genuine and democratic in classrooms, so that teachers can become willing to hand over more control to learners. 
To sum up, as a developing country, the education system at all levels in Turkey can benefit from the use of the Internet as a means of enabling learners, rather than teachers, to have more control in selecting, analysing, evaluating and applying information for their own purposes.

\section{References}

AKARSU, F. (1990). Unpublished research report on Turkish education.

BALCI, A. and YILDIRIM, A. (1999). 'Lisede sosyoloji dersinin öğretimi', 'ukurova Üniversitesi Ĕ̆itim Fakültesi Dergisi, 2, 17, 80-94.

BARNES, D. (1976). From Communication to Curriculum. Harmondsworth: Penguin.

BETT, S., FRENCH, D., FARR, G. and HOOKS, L. (1999). 'Augmenting traditional teaching with Internet-based options.' In: FRENCH, D., HALE, C., JOHNSON, C. and FARR, G. (Eds) Internet Based Learning: An Introduction and Framework for Higher Education and Business. London: Kogan Page.

BILHAN, S. (1991). 'Eğitim felsefesi: kavram çözümlemesi', Ankara Üniversitesi Eğitim Bilimleri Fakültesi Yayinlari, 164, 1, 1.

BOUD, D. (1981). Developing Student Autonomy in Learning. London: Kogan Page.

BOUD, D. (1995). 'Toward student responsibility for learning.' In: BOUD, D. (Ed) Enhancing Learning through Self-Assessment. London: Kogan Page.

BUTTERWORTH, G. E., HARRIS, P. L., LESLIE, M. A. and WELLMAN, H. M. (1991). Perspectives on the Child's Theory of Mind. Oxford: Oxford University Press.

BUYUKOZTURK, S. (1996). Türk Yükseköğretiminde Araştirma Eğitimi. Unpublished $\mathrm{PhD}$ thesis, Ankara Üniversitesi Sosyal Bilimler Enistitüsü.

COLLIS, B. and MEEUWSEN, E. (1999). 'Learning to learn in a www-based environment.' In: FRENCH, D., HALE, C., JOHNSON, C. and FARR, G. (Eds) Internet Based Learning: An Introduction and Framework for Higher Education and Business. London: Kogan Page.

DAM, L. (1995). Learner Autonomy 3: From Theory to Classroom Practice. Dublin: Authentik Language Learning Resources Ltd.

DAM, L. (2000). 'Why focus on learning rather than teaching? From theory into practice.' In: LITTLE, D., DAM, L. and TIMMER, J. (Eds) Focus on Learning rather than Teaching: Why and How? Papers from IATEFL Conference on Learner Independence. Krakow, 14-16th May 1998. Dublin: CLC, Trinity College.

DAM, L. and LITTLE, D. (1998). 'Autonomy in foreign language learning: from classroom practice to generalizable theory.' In: Proceedings of the FALT 24th Annual International Conference on Language Teaching and Learning, Educational Materials Expo, November. Omiya Sonic City, Omiya: JALT98 Proceedings.

DECI, E. (1996). Why We Do What We Do: Understanding Self-motivation. New York: Penguin.

ENGIN, C. and YILDIRIM, A. (1999). 'Lisedeki felsefe dersi öğretiminin değerlendirilmesi', ' ukurova Üniversitesi Ĕ̆itim Fakültesi Dergisi, 2, 17, 102-17.

FORSYTH, I. (1996). Teaching and Learning Materials and the Internet. London: Kogan Page.

FOX, R. (1991). 'Developing awareness of mind reflected in children's nature.' In: BUTTERWORTH, G., HARRIS, P. L., LESLIE, M. L. and WELLAM, H. M. (Eds) Perspectives on the Child's Theory of Mind. Oxford: Oxford University Press.

FRENCH, D. (1999). 'Preparing for the Internet-based learning.' In: FRENCH, D., HALE, C., JOHNSON, C. and FARR, G. (Eds) Internet Based Learning: An Introduction and Framework for Higher Education and Business. London: Kogan Page.

GREY, D. (1999). The Internet in School. London: Cassell.

GURUZ, K., SUHUBI, E., SENGOR, A. M. C., TURKER, K. and YURSEVER, E. (1994). Higher Education, Science and Technology in Turkey and in the World (in Turkish) (Publication No. TUSIAD-T/94, 6-167). Istanbul: TUSIAD. 
HOLEC, H. (1979). Autonomy and Foreign Language Learning. Oxford: Pergamon Press.

HOLEC, H., LITTLE, D. and RICHTERICH, R. (1996). Strategies in Language Learning and Use. Strasbourg: Council of Europe.

JOHNSON, C. (1999). 'Perspectives on the future of Internet-based learning.' In: FRENCH, D., HALE, C., JOHNSON, C. and FARR, G. (Eds) Internet Based Learning: An Introduction and Framework for Higher Education and Business. London: Kogan Page.

KARAGUL, T. (1996). Yüksek Öğretim Proğramlari için gerkli Öğrenci Yeterlilikleri ve Yükseköğretime Geçiş Süreci. Unpublished $\mathrm{PhD}$ thesis, Ankara Üniversitesi Sosyal Bilimler Enistitüsü.

KARASAR, N. (1974). 'Araştirma eğitimi', Ankara Üniversitesi Eğitim Fakültesi Dergisi, 7, 14, 263-74.

KARASAR, N. (1984). Türk Üniversitelerinde Araştirma Eğitimi. Unpublished PhD thesis; TUBITAK SAYG-E-49 PROJESI.

KEMMIS, S. (1989). 'Action research and the politics of reflection.' In: BOUD, D., KEOGH, R. and WALKER, D. (Eds) Reflection: Turning Experience into Learning. London: Kogan Page.

KENNY, B. (1993). 'Investigative research: how it changes learner status', TESOL Quarterly, 27, 2, 217-31.

KOHONEN, V. (1992). 'Experiential language learning: second language learning - a cooperative learner education.' In: NUNAN, D. (Ed) Collaborative Language Learning and Teaching. Cambridge: Cambridge University Press.

KOLB, D. A. (1984). Experiential Learning: Experience as the Source of Learning and Development. Englewood Cliffs, NJ: Prentice-Hall.

LIER, L. V. (1996). Interaction in the Language Curriculum: Awareness, Autonomy and Authenticity. London: Longman.

LITTLE, D. (1991). Learner Autonomy 1: Definitions, Issues and Problems. Dublin: Authentik Language Learning Resources Ltd.

LITTLE, D. (1996). 'Freedom to learn and compulsion to interact: promoting learner autonomy through the use of information systems and information technologies.' In: PEMBERTON, R. et al. (Eds) Taking Control: Autonomy in Language Learning. Hong Kong: Hong Kong University Press.

LITTLE, D. (1999). 'Developing learner autonomy in the foreign language classroom: a social interactive view of learning and three fundamental pedagogical principles', Revista Canaria De Estudios Ingleses, April, 38, 77-88.

LITTLE, D. (2000). 'Why focus on learning rather than teaching?' In: LITTLE, D., DAM, L. and TIMMER, L. (Eds) Focus on Learning rather than Teaching: Why and How? Papers from the IATEFL Conference on Learner Independence, Krakow, 14-16 May 1998. Dublin: CLC, Trinity College.

LYMAN, B. (1999). 'The Internet-based learning: what is in it for the adult learners?' In: FRENCH, D., HALE, C., JOHNSON, C. and FARR, G. (Eds) Internet Based Learning: An Introduction and Framework for Higher Education and Business. London: Kogan Page.

McKERNAN, J. (1996). Curriculum Action Research: A Handbook of Methods and Resources for the Reflective Practitioner. London: Kogan Page.

McLEAN, J. E. (1995). Improving Education through Action Research: A Guide for Administrators and Teachers: The Practicing Administrator's Leadership Series. Roadmaps to Success. Newbury Park, Calif.: Corwin Press.

MARTI, E. (1996). 'Mechanisms of internalization and externalization of knowledge in Piaget's and Vygotskian theories.' In: TRYPHON, A. and VONECHE, J. (Eds) The Social Genesis of Thought. London: Psychology Press.

NEWMARK, P. (1988). A Textbook of Translation. New York: Prentice-Hall.

PETERSON, M. (1997). 'Language teaching and networking', System, 25, 1, 29-37.

SALOMON, G. (1993). Distributed Cognitions: Psychological and Educational Considerations. Cambridge: Cambridge University Press.

SMITH, L. (1996). 'The social construction of rational understanding: Piaget-Vygotsky.' In: TRYPHON, A. and VONECHE, J. (Eds) The Social Genesis of Thought. London: Psychology Press. 
STEWART, C. and STOLLER, F. L. (1990). 'Critical thinking through opposing viewpoints', TESOL Nerwsletter, 24, 2, 4-5.

THARP, R. G. and GALLIMORE, R. (1988). Rousing Minds to Life: Teaching, Learning and Schooling in Social Context. Cambridge: Cambridge University Press.

TITIZ, M. T. (1998). Ezbersiz Egitim 'Yol Haritasi'. Ankara: Beyaz Yayinlari.

TYNJALA, P. (1997). 'Developing education students' conceptions of the learning process in different learning environments', Learning and Instruction, 7, 3, $277-92$.

USHIODA, E. (1996). Learner Autonomy 5: The Role of Motivation. Dublin: Authentik Language Learning Resources Ltd.

VYGOTSKY, L. S. (1962). Thought and Language. Cambridge, Mass.: MIT Press.

VYGOTSKY, L. S. (1978). 'The development of higher psychological processes.' In: COLE, M. et al. (Eds) Mind in Society. Cambridge, Mass.: Harvard University Press.

WELLMAN, H. M. (1990). The Child's Theory of Mind. Cambridge, Mass.: MIT Press.

YILDIRIM, A. (1997). 'Teaching and learning of middle school social studies in Turkey: an analysis of curriculum implementation', Mediterranean fournal of Educational Studies, 2, 2, 63-84.

\section{Appendix A: Pre-course questionnaire}

1 How would you translate a text? Explain *

\section{Questions 2-12: In your previous academic} experiences have you been encouraged to ...

2 do information searches for deeper subject knowledge for the source text to be translated?

3 do information searches for a deeper terminology (specific vocabulary) analysis for the source text to be translated?

4 question your learning method (how you learn)?

5 question what method of learning is more realistic/meaningful/applicable in real-life translations?

6 assess which method of learning is more meaningful to your own progress?

7 question the extent to which you base your analysis/translation of the source on data and evidence obtained through information searches?

8 assess the reliability of the evidence you obtain to enhance accuracy in your translation of the source text?

9 question how you can transfer the subject knowledge you developed in this course to your other academic courses and real-life situations when necessary?

10 question learning through information searches as meaningful and relevant to your needs in your other academic courses and real-life situations?

11 assess your progress of the subject knowledge you learned in this course?

12 assess your learning progress at a particular stage and overall?

Notes:

${ }^{\star}$ The only changes in the post-course questionnaire wording is as follows:

The wording of post-course questionnaire, question 1, is: 'How do you translate a text after taking this course? Explain.'

† The wording of the instructions for the post-course questionnaire, questions $2-12$ is: 'In this course, have you been encouraged to ...?? 


\section{Appendix B: Post-course interview questions}

1 How has the course changed your view of translation?

2 How has the course changed your view of learning?

3 How has the course encouraged you to assess your learning progress in general, and at a particular stage?

4 How will this experience affect your future learning?

5 What have you learned about yourself as a learner in the course?

6 How has the course encouraged you to think about your learning (what you were learning, why you were learning, how you were learning)?

7 How can you define your responsibilities in the course?

8 What difficulties did you experience in the course? 